\title{
Designing Game For Spirituality Education At Primary School
}

\author{
Rico Yupita, Ridwan Sanjaya, Bernardinus Harnadi \\ Department of Information System, Faculty of Computer Science, \\ Soegijapranata Catholic University, Semarang, Indonesia \\ 130700017@student.unika.ac.id, ridwan@unika.ac.id, bharnadi@unika.ac.id
}

\begin{abstract}
The purpose of this research is to find out the ways to make Catholic Subject learning more enjoyable, convenient, and helpful by designing "A New Me" game that were in accordance with primary student's necessity. This educational game was designed to teach students about the Fruit and Gifts of the Holy Spirit.

The game has been examined to 50 Primary School students in age range of 10-12 years old. The subject matter used is the Fruit and Gifts of the Holy Spirit.

The results of this research showned that the desire to play "A New Me" game is greatly influenced by the experience of playing digital games before, effort expectancy, enjoyment, and usability in playing the game.

Keyword- Digital class, Catholic Religion, Fruit and Gifts of the Holy Spirit, Education Game
\end{abstract}

\section{INTRODUCTION}

Based on the study case done in Theresiana 02 Primary School Semarang. The students mostly tought that the Catholic subject in school is conventional. But set aside students always think that Catholic subject in class is very important. By using the implemented digital class in Theresiana 02 Primary School then we can introduce the game called "A New Me".

The aim of the research is to find out how to make Catholic subject learning in class more enganging with designing the game which tailored with the students. On the other hand, to avoid any connection problem, the materials that implemented in digital class must be still able to run without any internet connection.
This research is being done in order to addressed these following research question. The research have purpose to solve the problems including: How to make Catholic Subject Learning more enganging; how to formulating game which tailored with Catholic Subject learning theme for student of primary school; and how to Digital Class program in school can delivered without any internet connection

\subsection{Agama}

\section{LITERATUR REVIEW}

The word "Agama" based on Sansekerta Languae that is "a" which mean "tidak" and "gama" which mean "kacau" and if combined it will result "tidak kacau" (teratur). [5] Meanwhile according to "Kamus Besar Bahasa Indonesia" (KBBI) "Agama"is a teaching that govern our believes to a certain God which corelate with humans interaction to its belief. [6] According to Daradjat "agama" is a teaching that govern our believes to a certain God which corelate with humans interaction to its belief, is a proccess of human interaction with his belief which he believes that there is something highers than human. While Glock and Stark define "agama" as symbol system, belief system, norm system and organized behavior system, which everything is centralized to the most meaningful problems in his lived out moment [5].

The function of religion for humans according Hendro Puspito are:

a. Educative Function

Educative function covers the task of teaching and guiding the success of 
education lies in the utilization of spiritual values which are at the core of the beliefs of each religion. Usually the values that are applied include the meaning and purpose of life, conscience, responsibility and God

b. Deliverance Function

The function of which his teachings provide safety deliverance to people who follow His teachings in the world and hereafter

c. Social Monitoring Function

Religion is responsible for social norms so that religion selects existing social norms, affirms the good and rejects anything bad to be abandoned and considered a prohibition. Religion also gives sanctions imposed on people who violate the prohibition and are closely monitored for its implementation

d. Transformative Function

The function where religion is able to make changes to the form of life of the old community to a new form of life

\subsection{Fruit of the Spirit and the Gift of the Spirit}

In the Epistle of the Apostle Paul to the Church in Galatians 5: 22-23, it is explained that the Fruit of the Spirit consists of 9 things, all of which are one entity, namely the Fruit of the Spirit, so that each part of the nine things is part of the unity of the Spirit Fruit. 9 of these things can be divided into 3 parts, namely:

a. Related to God which consists of Love, Joy and Peace

b. Related to humans which consists of patience. Mercy, and kindness

c. Related to oneself which consists of Loyalty, Gentleness, and Self Mastery.

Then for the gift of the Holy Spirit, in the

Epistle of the Apostle Paul to the church at

Corinth 12: 18-10 it is stated that there are 9 spiritual gifts given by the Holy Spirit. The nine gifts are then grouped into 3 groups as follows:

a. The gift of spiritual understanding, which consists of:

- Say with wisdom

- words with knowledge

- Distinguish various spirits b. A gift that manifests God's miraculous grace and strength

- Gift of Faith

- Gift for healing

- Gift for making miracles

c. A gift that expressed God's will

- A gift to prophesy

- Karunia untuk berbicara berbagai jenis Bahasa Roh*

- Gift for distinguish the Spirit

\subsection{Digital Class}

Digital classes is the class activities using as optimal as possible the role of the internet and digital technology in the preparation, implementation, assessment of learning; both students, teachers and parents; and for ongoing teacher professional development activities.[3]

The purpose application of digital class as learning system are :

a. Being an alternative source of learning for students in the digital age not only just from teachers in the classroom

b. Linking digital schools for learning and evaluation between schools with each other within the scope of SEA Digital Class (School of Southeast Asia)

c. Awareness efforts that we exist in the digital world and there is a new paradigm of learning

So far the private elementary school in Semarang that has implemented this system is only new to SD Theresiana 02 Semarang.

\subsection{Game}

The word of game derived from English words which means "permainan". "Permainan" is something that can be played that has certain rules so that there are players who win and there are losers who are usually not serious or just for entertainment purposes.

According to Parlett in the journal "IMPLEMENTASI METODE FONETIS PADA GAME EDUKASI MENYUSUN HURUF ALPHABET" mentioned the game is something that has an end and there are goals, results and a series of regulations to achieve both things [7]. 


\subsection{Educational Games}

Educational Games is a digital game designed for enrichment of education that supports learning teaching using interactive multimedia technology.

In designing educational games that are good, you must pay attention to and meet the following criteria:[8]

a. Overall Value

This value is centered on the design and the length of the game being played. The application is designed with an interactive and interesting design. As for playing time a timer feature is added in it.

b. Usabilitty

This value is very important in making games. This application designs a system with a user friendly interface so that users can easily access the application

c. Accuracy

Accuracy is defined as how the success of the drawing model of a game is poured into experiments or design. The design of each application must be in accordance with the game model at the planning stage

d. Appropriatness

Conformity is interpreted in how the content and design of the game are adapted to user requirements properly. This application provides menus and features needed by the user to help understand the user in using the application

\section{METHOD \\ 3.1 Object and Research Location}

Object of observation for this Religion Educational Game is a students of Primary School 5th and 6th Immersion Program and was done at Theresiana School 02 Semarang.

\subsection{Population and Sample}

Population is the total of individual that have certain characteristics determined by researchers to be studied before conclusions can be drawn. While the sample is a small part of a population. Samples should be representative or really can represent the characteristics of the entire population
In this research, the population of children aged 10 - 12 years old with a sample room of 50 people.

\subsection{Research Method}

Research method is a method used to collect data needed in research. Data collection for Catholic religious game material was done by asking questions to the teacher who given the Catholic subject in the School.

Before students played the game. While post test data was distributed after students played the game.

\section{4 . Literature Review}

Literature study is to gather information that is relevant to the topic based on its research. Sources of study usually come from scientific books, research reports, and printed and electronic journals.

The source of this literature comes from journals and articles relating to the Study of Catholic Religion, especially regarding the Gifts and Fruits of the Holy Spirit starting from the types and examples in everyday life and people around.

\subsection{Questionnaire}

Questionnaire is a method of collecting data by giving a number of questions or statements that are written to the respondent to obtain information. Distribution of questionnaires was carried out in 2 stages, namely before playing the game (pre-test) and after playing the game 2-4 times (post test)

\subsection{Research Instrument}

The research instrument is a tool in collecting data. The form of the research instrument depends on the data needed in a study. In this study journals, research reports and written and electronic articles have been used as a tool in the preparation of the basic concepts of the game. In measuring the respondent's knowledge about the Catholic religious lesson game the questionnaire was used to find out how much the impact of the game "A New $\mathrm{Me}^{\mathrm{N}}$ for elementary school 
students Theresiana 02 as an alternative learning media.

\subsection{Game Development Method}

Here is the Game Development Method flowchart of game A New.

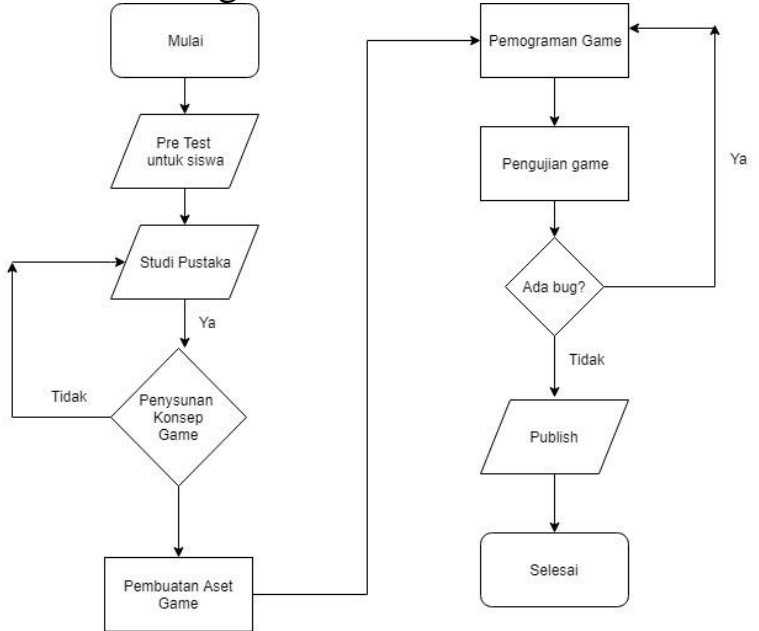

Picture 3.1. Game Development Method Flowchart

The development of A New Me game begins with the search for data on Catholic elementary schools that apply Digital Class as a lesson and then meet the teacher of Catholic teaching at the school to ask about the material to be used. After getting the material to be used, it will continue with determining the gameplay that will be used in the game. After that the process continues to design the game flow (game design) into the storyboard so that the flow can be clearly understood. The next process is making game assets that will be used such as background games, UI, objects and SFX (sound effects) that will be used later in the game. After the creation and search for assets, it was continued to make games using the Construct 2 game engine and when it was finished it was tested to find and justify bugs and errors.

\subsection{Framework}

Here is the workflow diagram of this research.

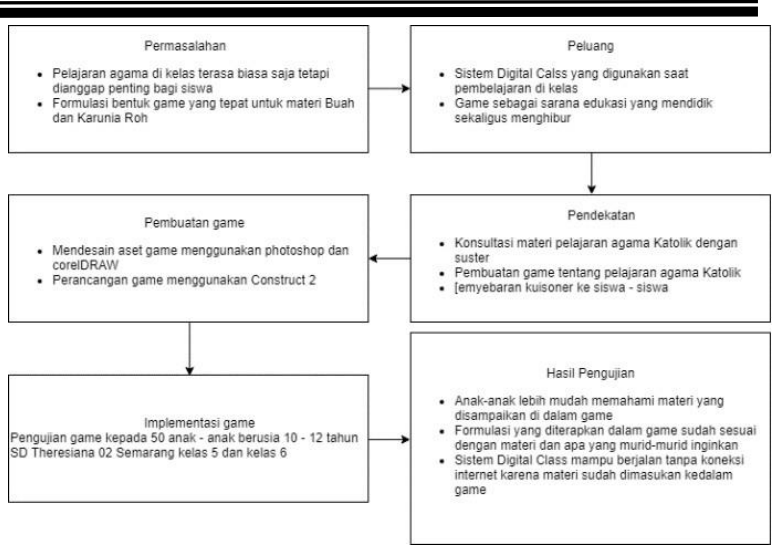

Picture 3.2 Workflow Diagram

\section{RESULTS AND DISCUSSION \\ 4.1 Game Assets Design}

Asset design begins with searching for the reference images and then recreating them using Adobe Photoshop CC and CorelDRAW.

Here is some example of game assets design.

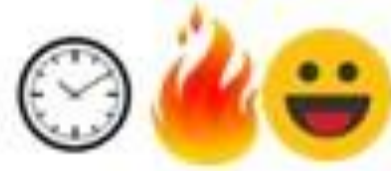

\section{Gambar 4.1 Gambar beberapa aset level 2}

In the game there are various buttons that function as navigation from one menu to another menu or moving objects Here are some key designs used in the A New Me game.

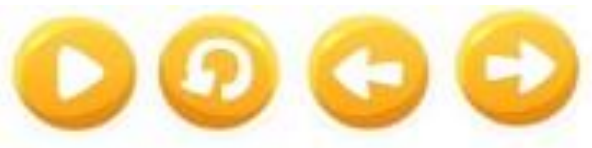

\section{Picture 4.3 Game Icon Design}

In order to make the game look more attractive, a background for this game was made and the following is the background design for playing the A New Me game menu.

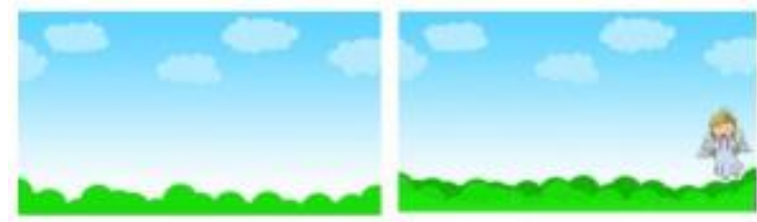

Gambar 4.4 Desain Background

In the game there is also a pop up to display the acquisition of each level played. This pop up result contains the number of scores and stars obtained. Next is the design of the score pop up and reward. 

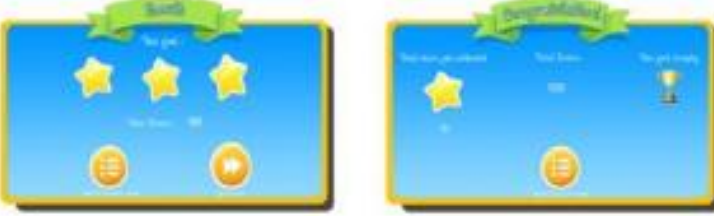

\section{Gambar 4.6 Pop Up Result dan Congratulation Screen}

\subsection{Game Flow}

Here is the flow of the game A New Me

\subsubsection{Quiz of Life}

At this level players are invited to choose which actions are good and which are bad. The questions that arise are as many as 10 of the 30 random questions. If the player chooses the correct answer then he will get a score of 10 and if wrong then the score will be reduced by 5 points plus a reduction in health and cannot continue to the next question.

\subsubsection{Catch the fruit of Holy Spirit}

At this level players are invited to capture 9 pieces - the fruit of the Holy Spirit which is symbolized in the form of symbols of objects commonly found in everyday life. Players must collect as many scores as possible within 90 seconds. At this level players are also provided with bonuses that can be used to increase time or increase scores. There is also a slider that is used to speed up the speed of falling rather than fruits. Besides adding the slider speed it also functions as a multipier score which is divided into 3 zones. Green zone (slow) multiples 1. Orange (medium) multiples of 2, and highest zones, namely red (fast) as many as multiples 3. Players will be game over if they catch a symbol that reduces time and scores 3 times.

\subsection{Gift of the Holy Spirits at People Around You}

At this level the players are invited to guess the gifts of the Holy Spirit available to those who commonly found in everyday life. If the player answers correctly then the player will get 10 points and if one gets a score of 5 points with a health reduction.

\subsection{Bonus Level - Fruit of Life}

At this level bonus the player is invited to determine what good deed is and what is bad about how to enter the fruit that comes up with its statement and provided 2 good and bad baskets. The score is obtained if the player enters the statement fruit into the correct basket will get a score of 25 and if one gets only 10 points.

\subsection{Achievement System}

This achievement system is based on stars and the scores collected at all levels will receive a trophy. If the score obtained is more than 1600, it will get 3 big gold trophies, if the score obtained is between 1200-1599, then you will get 2 medium silver trophies, and if you score below 1199 you will get a small bronze trophy.

\subsection{Game Testing}

Game testing is done after the respondent completes the pre-test and plays the game 2-5 times. The results of the questionnaire were used to reveal the Resoinden encryption, and test the variable correlation of the study. Before testing the correlation, test the validity of questionnaire variables and reliability test on the research variables.

\subsubsection{Biographic Data}

This data is in the form contains class, age, and gender of the students of SD Theresiana 02 Semarang. Here is the data .

Tabel 4.1 Tabel Biografis

\begin{tabular}{|l|l|l|}
\hline \multicolumn{3}{|c|}{ AGES } \\
\hline Ages & Frequention & Persentation \\
\hline 10 & 6 & $12 \%$ \\
\hline 11 & 22 & $44 \%$ \\
\hline 12 & 22 & $44 \%$ \\
\hline Grades & Persentation \\
\hline Grades & Frequention & $44 \%$ \\
\hline Primary 6A & 22 & $56 \%$ \\
\hline Primary 6A & 28 & \\
\hline Gender & Frequention & Persentation \\
\hline Gender & 29 & $58 \%$ \\
\hline Male & 21 & $42 \%$ \\
\hline Female &
\end{tabular}

\subsubsection{Testing Model}

In the testing model there are independent variable which consist of Effort Expectancy (EE), Usability (US), Enjoyment (EJ), Compatibility (CO) and dependent variable which is Intention (IT). This following of the testing chart : 


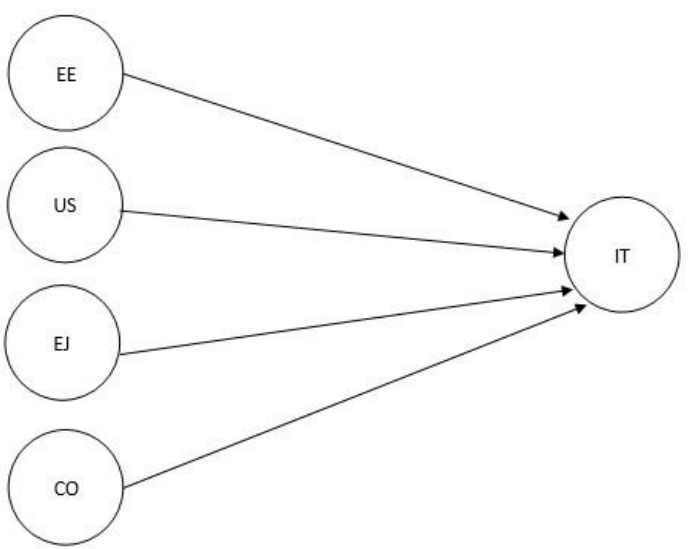

Picture 4.xx Testing Model

Testing hypothesis :

1. Effort Expectancy (EE) variable has strong effect with someone intention (IT) to playing A New Me game

2. Usability (US) variable has strong effect with someone intention (IT) to playing A New Me game

3. Enjoyment (EJ) variable has strong effect with someone intention (IT) to playing A New Me game

4. Compability (CO) variable memiliki pengaruh yang kuat terhadap Intensi (IT) seseorang untuk memainkan game A New $\mathrm{Me}$

\subsubsection{Variable Testing}

\subsubsection{Variable Validity Test}

All variables must be tested for validity to ensure questions can represent each of the true variables and represent the attitudes of the respondents. To test the validity of each variable used, the Principal Component Factor Analysis test is performed. After the experiment, the validity of the variables EE3, $\mathrm{EJ} 1, \mathrm{CO} 1$, and $\mathrm{CO} 3$ is invalid after comparison with $r$ table. So from that it was retested by not including variables EE3, EJ1, $\mathrm{CO} 1$, and $\mathrm{CO} 3$

\begin{tabular}{l|l|l|l|l} 
& N Table & $\begin{array}{l}\text { Corrected } \\
\text { Item-Total } \\
\text { Correlation }\end{array}$ & r Table & Description \\
\hline EE1 & 50 & .409 & .281 & Valid \\
\hline EE2 & 50 & .400 & .281 & Valid \\
\hline EE3 & 50 & .275 & .281 & Not Valid \\
\hline US1 & 50 & .392 & .281 & Valid \\
\hline US2 & 50 & .378 & .281 & Valid \\
\hline US3 & 50 & .540 & .281 & Valid \\
\hline EJ1 & 50 & .254 & .281 & Not Valid \\
\hline EJ2 & 50 & .318 & .281 & Valid \\
\hline EJ3 & 50 & .399 & .281 & Valid \\
\hline CO1 & 50 & .213 & .281 & Not Valid \\
\hline CO2 & 50 & .443 & .281 & Valid \\
\hline CO3 & 50 & .233 & .281 & Not Valid \\
\hline IT1 & 50 & .557 & .281 & Valid \\
\hline IT2 & 50 & .643 & .281 & Valid \\
\hline IT3 & 50 & .503 & .281 & Valid \\
\hline & & & &
\end{tabular}

After variables EE3, EJ1, CO1, and $\mathrm{CO} 3$ are not included, then tested with use Principal Component Factor Analysis to show the level of convergence of indicators in each variable. After the testing, the results turned out to be convergent and in accordance with the Principal Component Factor Analysis. The following is a rotated compenent matrix table that shows from the test.

\begin{tabular}{|l|l|l|l}
\hline EE1 & .016 & .138 & .754 \\
\hline EE2 & .019 & .076 & .752 \\
\hline US1 & .080 & .907 &. .066 \\
\hline US2 & .092 & .867 & -.015 \\
\hline US3 & .202 & .779 & .180 \\
\hline EJ2 & .255 & -.179 & .671 \\
\hline EJ3 & .445 & .007 & .455 \\
\hline IT1 & .895 & .120 & .105 \\
\hline IT2 & .902 & .177 & .183 \\
\hline IT3 & .922 & .161 & .028 \\
\hline
\end{tabular}

Thus the variable declared valida used in the next test is EE1, EE2, US1, US2, US3, EJ2, EJ3, IT1, IT2, and IT3.

\subsubsection{Variable Reliability Test}

Cronbach's Alpha coefficient is used for reliability testing to determine the level of confidence in the questionnaire. Here is a table of reliability test results. 


\begin{tabular}{|c|c|c|}
\hline Variables & $\begin{array}{c}\text { Cronbach's } \\
\text { Alpha }\end{array}$ & $\begin{array}{c}\text { Internal } \\
\text { Consistency }\end{array}$ \\
\hline EE & 0.600 & Questionable \\
\hline US & 0.834 & Good \\
\hline EJ & 0.628 & Questionable \\
\hline IT & 0.931 & Excellent \\
\hline
\end{tabular}

Here is the Table of Cronbach's Alpha

\begin{tabular}{|l|l|}
\hline Cronbach's alpha & Internal consistency \\
\hline$a \geq 0.9$ & Excellent \\
\hline $0.9>a \geq 0.8$ & Good \\
\hline $0.8>a \geq 0.7$ & Acceptable \\
\hline $0.7>a \geq 0.6$ & Questionable \\
\hline $0.6>a \geq 0.5$ & Poor \\
\hline $0.5>a$ & Unacceptable \\
\hline
\end{tabular}

\subsubsection{Corelation Test}

The hypothesis used in the study uses correlation tests between variables, to test whether the variables Expectancy (EE), Usability (US), Enjoyment (EJ), Compability (CO), and Intention (IT) In table 4.10 it can be seen that the desire to play games "A New $\mathrm{Me}$ " is greatly influenced by experience of playing digital games, effort expectancy, enjoyment, and usability in addition to increasing the desire or intention to play the "A New Me" game must be fun and easy to access by any gadget.

\subsection{Conclusion}

\section{CONCLUSION}

The conclusions obtained from the research on Android Based Game for Catholic Subject at Primary school are :

1. The way to play a fun Catholic religious education game is to formulate a game that suits the children so that when the game is played it will be interesting and fun for children. The game is made in the form of mini games with the theme of Fruit and Spirit Gifts, where there are 4 levels that must be played by the children who play it

2. The formulation of the right game form in the delivery of Catholic-themed games is casual gaming, which makes games that are classified as light and easy for children such as trivia, drag and drop games, guessing images and capturing falling objects. Trivia games that contain questions related to everyday life where players must choose what actions are based on 9 pieces of the Spirit and which are not (which ones are good which are bad). A guessing game where players have to guess the picture of work related to the gift of holy spirit. Drag and drop games are games where the player must determine which is good and which is bad with the child who will mention the actions and provided a basket for good and bad. Then the game captures the falling object where it must capture the fruits that represent the 9 pieces of the Holy Spirit.

3. The game A New Me successfully runs and is played by children in the class without using an internet connection because all assets and material that is camouflaged have been entered into the game created.

\subsection{Suggestion}

The suggestions that can be considered for further research are:

1. Add variety of types of games that are more diverse and are followed by the addition of Catholic subject matter to see the effect of the game on the material absorbed by students.

2. Improved visuals of the game such as the addition of better animation and the use of music that is more suitable and its influence on the attraction of the game's completion

3. Adding story lines and see the impact on the interest in playing the game.

\section{REFERENCES}

[1] "Pentingnya Pendidikan Agama Katolik di Sekolah - Paroki Citra Raya - Cikupa Tangerang." [Online]. Available: http://parokicitraraya.org/2017/01/05/p entingny a-pendidikan-agama-katolikdi-sekolah/. [Accessed: 24-Apr-2019].

[2] Sudjana dan Rivai, "Media Pembelajaran.," pp. 1-23, 2011. 
[3] "Semarang Digital Class (SDC)," Semarang Digital Class. [Online].

Available:

http://semarangdigitalclass.com/.

[Accessed: 23- Oct-2018].

[4] "Theresiana Implementasikan Digital

Class - Direktorat Sekolah

Theresiana Yayasan Bernardus,"

Theresiana Implementasikan Digital

Class, 2016. [Online]. Available: http://www.theresiana.sch.id/internal/se kolah- theresiana-mengiplementasikandigital-class. [Accessed: 23-Oct-2018].

[5] Kebudayaan, Agama, and Jogyakarta, "Kajian Teori Keberagamaan," Pengantar Sosiol. Agama, vol. 13, pp. 23-81, 1992.

[6] "Arti kata agama - Kamus Besar Bahasa Indonesia (KBBI) Online," Arti Kata Agama. [Online]. Available: https://kbbi.web.id/agama. [Accessed: 23-Oct-2018].

[7] H. Mukhlis, "Implementasi Metode Fonetis pada Game Edukasi Menyusun Huruf Alphabet," no. 0911324, pp. 150-154, 2015.

[8] Dora et.al, "Perancangan Aplikasi Game Edukasi Pembelajaran Anak Usia Dini Menggunakan Linear Congruent Method (Lcm) Berbasis Android," J. Inform. Glob., vol. 6, no.1, pp. 7-14, 2015. 